\title{
Liquid biopsies in myeloid malignancies
}

\section{Bilal Abdulmawjood, Catarina Roma-Rodrigues, Alexandra R. Fernandes, Pedro V. Baptista}

UCIBIO, Department of Life Sciences, Faculdade de Ciências e Tecnologia, Universidade NOVA de Lisboa, Campus Caparica, Caparica 2829-516, Portugal.

Correspondence to: Prof. Alexandra R. Fernandes and Pedro V. Baptista, UCIBIO, Department of Life Sciences, Faculdade Ciências e Tecnologia, Universidade NOVA de Lisboa, Caparica 2829-516, Portugal. E-mail: ma.fernandes@fct.unl.pt; pmvb@fct.unl.pt

\begin{abstract}
How to cite this article: Abdulmawjood B, Roma-Rodrigues C, Fernandes AR, Baptista PV. Liquid biopsies in myeloid malignancies. Cancer Drug Resist2019;2:1044-61. http://dx.doi.org/10.20517/cdr.2019.88
\end{abstract}

Received: 30 Sep 2019 First Decision: 3 Dec 2019 Revised: 6 Dec 2019 Accepted: 10 Dec 2019 Published: 19 Dec 2019

Science Editor: Dario Marchetti Copy Editor: Jing-Wen Zhang Production Editor: Tian Zhang

\begin{abstract}
Hematologic malignancies are the most common type of cancer affecting children and young adults, and encompass diseases, such as leukemia, lymphoma, and myeloma, all of which impact blood associated tissues such as the bone marrow, lymphatic system, and blood cells. Clinical diagnostics of these malignancies relies heavily on the use of bone marrow samples, which is painful, debilitating, and not free from risks for leukemia patients. Liquid biopsies are based on minimally invasive assessment of markers in the blood (and other fluids) and have the potential to improve the efficacy of diagnostic/therapeutic strategies in leukemia patients, providing a useful tool for the real time molecular profiling of patients. The most promising noninvasive biomarkers are circulating tumor cells, circulating tumor DNA, microRNAs, and exosomes. Herein, we discuss the role of assessing these circulating biomarkers for the understanding of tumor progression and metastasis, tumor progression dynamics through treatment and for follow-up.
\end{abstract}

Keywords: Liquid biopsy, circulating tumor cells, circulating tumor DNA, exosomes, microRNAs, leukemia

\section{INTRODUCTION}

Hematologic malignancies, characterized as affecting the bone marrow, lymphatic system, and blood cells, are the most common kind of cancer among children and young adults. Leukemia, lymphoma, and myeloma are amongst the most frequent presentations within this group of blood related disorders ${ }^{[1]}$. Throughout the sequential stages of hematopoietic differentiation, there are plenty of occasions for disruptive biomolecular events to occur (e.g., mutations) that will then promote and/or result in dissimilar cancer subtypes and clinical presentations ${ }^{[2]}$.

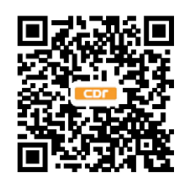


Leukemia may be defined as a cancer that derives from the bone marrow and affects hematopoiesis ${ }^{[3]}$. This malignancy results from an abnormal proliferation of white blood cells in the bone marrow, which then affects the normal development of cells, and may even spread to other organs such as the spleen, the liver, the meninges, lymph nodes, etc. ${ }^{[4]}$. Because of the wide variability of white blood cells in the human body, leukemia differs greatly from other types of cancers and may affect people of all ages, from young children to the elderly. In addition, unlike most cancers, population characteristics, such as age, race, and lifestyle, do not exempt from being at risk. Leukemias account for over 50,000 new cancer cases annually ${ }^{[5]}$. Leukemia is generally divided into two types, depending on how quickly the immature cells (blasts) proliferate: (1) acute leukemia; or (2) chronic leukemia ${ }^{[6]}$. Leukemia can be further grouped considering the cell lineage affected either myeloid or lymphoid. As such, leukemias may be grouped into acute myeloid leukemia (AML), chronic myeloid leukemia (CML), acute lymphoblastic leukemia (ALL), and chronic lymphocytic leukemia (CLL) ${ }^{[7-11]}$. Myelodysplastic syndromes (MDS) constitute a particular cohort of hematopoietic myeloid stem cell conditions that has not been completely recognized as such and, sometimes, lack full characterization. However, MDS show strong features of hematologic malignancies with major impact on the patients' quality of life ${ }^{[12,13]}$. Herein, we focus on liquid biopsies (LB) within the scope of AML, CML, and MDS.

\section{Myeloid leukemia}

$A M L$

Similar to other malignant hematopoietic diseases, AML results from an accumulation of immature myeloid blast cells in the bone marrow that often extends to the circulating blood ${ }^{[1,15]}$. However, AML may also affect other tissues, such as the skin (leukemia cutis). AML is a severe life-threatening disease that may arise in all ages but is more common in the elderly with a median age at diagnosis of approximately 70 years ${ }^{[16,17]}$. AML presentation is highly heterogeneous and individual cases are characterized by a wide variety of cytogenetic and molecular defects. For instance, the French-American-British classification proposes that AML should be classified according to a particular score (Mo-M7) according morphological and cytochemical criteria ${ }^{[18,19]}$. For example, about $41 \%$ of AML patients have a normal karyotype, but several chromosomal translocations have been described, such as $\mathrm{t}(15 ; 17)$ (q22; q21) in $13 \%$ of patients; $\mathrm{t}$ (8; 21) (q22; q22) in $7 \%$ of reported cases; and inv (16) (p13; q22)/t $(16 ; 16)(\mathrm{p} 13 ; \mathrm{q} 22)$ in $5 \%$ of cases ${ }^{[18]}$. Some of these chromosomal alterations lead to the expression of abnormal fusion proteins with oncogenic potential, or to the inactivation of tumor suppressor genes ${ }^{[20]}$. It should be noted that AML with normal cytogenetics is very heterogeneous in its clinical and molecular features, and its pathogenesis is much less clear than that of AML with chromosomal rearrangements. Two of the most frequent such rearrangements occur in two well-known genes, namely NPM1 (nucleophosmin protein, NPM1) and FLT3 (fms-like tyrosine kinase 3 protein, FLT3), whose mutational status support prognostics in the clinical assessment ${ }^{[21]}$.

$C M L$

CML is a rare malignant proliferative disease of the hematopoietic system with a worldwide incidence of 10-12 new cases per 100,000 habitants per year ${ }^{[22]}$. The molecular hallmark of CML is the Philadelphia chromosome $(\mathrm{Ph})$ that originates from the reciprocal translocation $\mathrm{t}(9 ; 22)$ (q34; q11), between the breakpoint cluster region $(\mathrm{BCR})$ and the Abelson tyrosine kinase (ABL), which produces a fusion gene $B C R-A B L^{[23]}$. This gene yields the BCR-ABL oncoprotein, a constitutively activated tyrosine kinase, capable of recruiting and activating several pathways regulating the transduction of intracellular signals, and ultimately resulting in abnormal cellular adhesion, enhanced proliferation, and inhibition of apoptosis ${ }^{[24,25]}$. Disease progression begins by a chronic phase (3-6 years), an accelerated phase follows characterized by clonal transformation. Ultimately, a short terminal blast phase occurs ${ }^{[26,27]}$. One of the first chemical compounds to be used against CML was Arsenic, which was later replaced by X-ray irradiation of the spleen ${ }^{[28]}$. During the early 1970s, the use of busulfan and hydroxyurea for the treatment of CML, which greatly improved the quality of life during the chronic phase of CML, but without preventing or delaying 
progression to advanced accelerated phase and blast phase ${ }^{[29]}$. In the late 1970 s and early 1980s, bone marrow transplantation (allogeneic hematopoietic stem cell transplantation, allo-HSCT) was introduced that allowed completely eradicating the $\mathrm{Ph}$ positive cells in the bone marrow and, thus, provided a cure for CML patients ${ }^{[30-32]}$. In 1983, Interferon alpha (IFN $)$ was reported to significantly reduce the number of white blood cells and induce a cytogenetic response in some CML patients ${ }^{[33]}$. However, the gold standard in CML treatment began with the discovery of Tyrosine Kinase Inhibitors (TIs), which selectively block the activity of the fusion oncoprotein, radically changing the way clinicians approach this disease. The first TKI used in CML therapy was imatinib, which functions as a competitive inhibitor binding to the ATP pocket in the kinase domain, with response rates of over $95 \%{ }^{[34,35]}$. Second and third generations of TKIs, such as dasatinib, nilotinib, bosutinib, and ponatinib, have subsequently been introduced, improving the efficiency of CML chemotherapy ${ }^{[36]}$.

\section{MDS}

With a yearly incidence of 4:100,000 (prevalence 7:100,000), MDS constitute a group of extremely frequent hematological malignancies, characterized by disruption of the bone marrow stroma, with poor differentiation and maturation. The incidence of MDS rises sharply with age, reaching 50:100,000/year above 80 years of age ${ }^{[37,38]}$. However, the median age at onset is around 70 years, with only $10 \%$ of MDS diagnosed patients under the age of $50^{[37-41]}$. There is an important clinical criterion for MDS diagnosis that is a constant cytopenia for more than three months (other conditions that may cause cytopenia must have been excluded), which is usually accompanied by a reduction of blood cell counts. These patients show an increased risk (20\%-25\%) of developing $\mathrm{AML}^{[41,42]}$. For accurate MDS clinical diagnosis, several features are considered: (1) dysplasia in more than $10 \%$ of cells within one or more cell lineages; (2) more than $15 \%$ of ring sideroblasts; (3) cytogenetic abnormalities; and (4) mutations in the splicing factor SF3B1 in combination with $>5 \%$ ring sideroblasts ${ }^{[43-45]}$.

\section{LB}

Biopsies are medical procedures that involve taking a small sample of tissue to be examined and evaluated, and they have been used by clinicians to diagnose and manage diseases for more than 1000 years ${ }^{[46]}$. In cancer patients, biopsies are critical for the full histopathological characterization and staging of the disease, and they may also provide material for the characterization of the genetic profile of the tumor, which is key in enabling the projection of disease progression and the response to therapy ${ }^{[47]}$. Despite current advances in cancer diagnosis and treatment, traditional biopsies require invasive procedures (e.g., surgery), which may have potential complications, sometimes cannot be repeated for sampling, and are limited in use when the patients' health status has decayed considerably or when the tumor is not accessible $^{[48]}$. The genomic profile of biopsies provides a portrait of the cancer itself and of the considerable genetic heterogeneity of the several subclones that constitute the "tumor", but they show a tremendous drawback: they are limited to assessing only a snapshot of the tumor rather than the whole dynamic process $^{[49]}$. In fact, it has been widely recognized that the genome context of tumors (and their metastasis) show a dynamic development in time, frequently as a response to the selective pressure of the surrounding (microenvironment) and/or of the challenging chemo- and radiotherapies (acquired resistance) that are used to tackle cancer development and that might trigger the evolution of diverse cell clones ${ }^{[48]}$. For these reasons, in recent years, there has been a strong focus on retrieving a more comprehensive overview of the disease by analyzing tumor material directly in blood ${ }^{[49]}$.

Biopsies of peripheral blood are called LB and represent a novel and more comprehensive approach to obtain robust molecular information from the tumor ${ }^{[50]}$. Apoptotic and necrotic cancer cells release into the blood/lymph circulation plenty of circulating DNA fragments (circulating tumor DNA, ctDNA), together with a multitude of small vesicles, namely exosomes (EXOs), which are small vesicles released by cells that include proteins and nucleic acids ${ }^{[47-49,51]}$. In many situations, LB allow for imaging techniques 
and/or re-biopsy. Perhaps the biggest benefit of LB is that retrieving the critical sample fluid is much less invasive than their solid counterparts, or even some imaging approaches relying on the use of contrast agents $^{[52]}$. Another advantage of using LB is the possibility of improved early diagnosis. In some advanced staged cancers, ctDNA may be detected in three out of four patients ${ }^{[53,54]}$. A strong case for LBs has been put forward by the European Society for Medical Oncology that has proposed to use LB to re-biopsy for assessing the genomic mutation status of Epidermal Growth Factor (EGFR) in patients ${ }^{[55,56]}$, which is strongly associated to drug response and the development of drug resistance mechanisms for these types of drugs. However, the possibility to assess the molecular evolution of these malignancies makes LBs a valuable tool to screen and identify alterations associated to drug response and, more relevant, profiles correlating to the development of drug resistance.

In fact, it is not the case of LB versus solid biopsies, but rather the complementary information that might be retrieved by using a combination of these approaches. When used together, LB allows for a more comprehensive characterization of tumor heterogeneity, but with a less invasive procedure that decreases the eventual discomfort to the patient. As such, it is possible to retrieve more information on the dynamics of molecular changes of cancer cells ${ }^{[5]]}$, which is critical for the assessment of therapeutic follow-up. LB opens up new possibilities for clinical characterization of malignancies for: (1) clinical management of advanced stage cancers; (2) prognosis of response to therapeutics; (3) detection of recurrence; and (4) evaluation of tumor genomic evolution ${ }^{[47,57]}$.

\section{ctDNA}

During their lifespan, cells may release portions of DNA via numerous normal and pathological mechanisms. In normal conditions, cell free DNA (cfDNA) that is release from cells undergoing apoptosis and/or necrosis is rapidly taken up by the immune system, i.e., tissue macrophages ${ }^{[58,59]}$. However, the phagocytosis system may be overwhelmed and, as a result, higher amounts of DNA fragments reach the bloodstream. This DNA degradation frequently occurs during apoptosis, resulting in fragmentation of chromatin into nucleosomes that originate cfDNA fragments of 180-200 base pairs (bp ${ }^{[60]}$. Living tumor cells also release ctDNA into the bloodstream, which may then mediate further malignant transformation and metastasis ${ }^{[61]}$.

However, differences exist between the length ctDNA and cfDNA fragments. For example, some human cancers present a ctDNA rich fraction encompassing fragments that are circa 20-50 bp shorter than that of cfDNA of healthy donors ${ }^{[62]}$. ctDNA has several molecular characteristics associated with the tumor of origin, such as mutation pattern, copy number variations (CNVs), and methylation level ${ }^{[63-67]}$. ctDNA is predominantly found in plasma and serum, but it has also been recovered from other body fluids, such as breast milk, bone marrow, etc. ${ }^{[68]}$. Generally, circulating nucleic acids show half-lives between $15 \mathrm{~min}$ and several hours before being removed from circulation by the liver and kidney ${ }^{[69,70]}$.

One of the main concerns when analyzing cfDNA is the possibility of contamination by genomic DNA (e.g., that might be released from circulating blood cells or endothelia). This may be circumvented by using plasma rather than serum as LB for cfDNA analysis ${ }^{[7]}$. There have been several reports putting forward the use of other body fluids, such as urine ${ }^{[72]}$, saliva ${ }^{[73]}$, and cerebrospinal fluid ${ }^{[74]}$, as a substitute for plasma as a source of sizeable amounts of ctDNA. In LB targeting cfDNA, it is recommended to use anticoagulants that may also act as nuclease inhibitors, such as ethylenediaminetetraacetic acid (EDTA). Caution should be paid to the fact that excess EDTA may hamper the efficiency of the downstream enzymatic reactions, such as those used in amplification protocols (e.g., polymerase chain reaction, $\mathrm{PCR})^{[75]}$. The major drawback of using blood as LB is the presence of genomic DNA derived from circulating blood cells that would both affect concentration of cfDNA and introduce bias in terms of sequence analysis ${ }^{[76]}$. In addition, transport 
and storage conditions affect cfDNA amounts, since non-optimal temperature and mechanical stress might induce cell lysis that release cfDNA into the collected sample ${ }^{[77]}$.

The potential of cfDNA for cancer genetic profiling has been recognized since the end of World War $\mathrm{II}^{[78]}$. Some thirty years later, it was already accepted that cancer patients showed elevated levels of cfDNA in peripheral blood. The average cfDNA concentration is almost 400 times higher for cancer patients, when compared to the healthy individuals ${ }^{[79]}$. The highest levels were observed in patients with advanced metastatic disease resistant to chemotherapy and poor prognosis ${ }^{[79]}$. The relevance of cfDNA analysis in hematological malignancies was reinforced by showing that possibility to assess specific mutation status associated to malignancy, such as NRAS mutations in MDS and $\mathrm{AML}^{[80]}$. In 2013, the first report of cancer detection using cfDNA from a pregnant woman showed the correlation between the non-invasive prenatal testing suggestive of an aneuploidy for chromosomes 13 and 18 (that targets fetal cfDNA in maternal cfDNA) and a small cell carcinoma with aneuploidy in 80\% of analyzed cells, including chromosomes 13 and $18^{[81,82]}$.

Currently, ctDNA analysis is used for both for direct diagnosis and to assess tumor progression, particularly useful to evaluate the molecular response to therapeutics. These analyses can be performed using both manual and automated systems able to extract ctDNA from plasma ${ }^{[83,84]}$. ctDNA has also been used to assess tumor burden and for multiplex analysis of gene mutations, including the customary biomarkers: EGFR, HER-2, BRAF, KRAS, ALK, and $\mathrm{KIT}^{[85]}$. Additionally, mounting evidence indicates that ctDNA is extremely useful for the identification of mutations associated to treatment options ${ }^{[83,86,87]}$. In addition, even CNVs, which may be difficult to analyze, have been successfully screened ${ }^{[85]}$. A recent approach has been reported to be used for the diagnostics of eight common cancer types through the assessment of mutations in cfDNA-CancerSEEK ${ }^{[88]}$.

The growing knowledge that a particular tumor may evolve through the expansion of heterogenous genetically distinct subclones originating from sequence alterations has triggered the interest in assessing the frequency, identity, and molecular evolution of these clones. The difficulties in performing these analyses from traditional biopsies has redirected clinicians to use LB, with the possibility to follow the succession of occurring molecular events ${ }^{[89,90]}$. In fact, the evolutionary phylogenetic subclone analysis in non-small cell lung carcinoma (NSCLC) was possible via the utilization of ctDNA collected over 30 weeks ${ }^{[90]}$. From the reported data, it becomes clear that ctDNA may be used for the molecular analysis of subclones of a primary tumor that only exist in small sizes. In addition, the use of ctDNA also allowed characterizing metastatic subclones from the primary tumor that could be used as a specific tumor marker for evaluating response to in NSCLC ${ }^{[0,91]}$.

\section{Circulating tumor cells}

The first description of the ability of cancer cells to travel through the bloodstream and metastasize in distant tissues and organs was reported in the late 19 th century ${ }^{[92]}$. During the same period, several studies culminated in the discovery of circulating tumor cells (CTCs) that consisted of tumor cells circulating in the bloodstream whose characteristics strongly resemble those of an existing tumor ${ }^{[93]}$. It is generally accepted that CTCs may be shed from tumor sites, be it the primary tumor or secondary metastatic tissue, directly into circulation. Perhaps it is the relationship between CTCs' tumorgenicity and their "traveling" capability that has made them a pivotal element in the processes leading to the development of metastases ${ }^{[94]}$. CTCs are nucleated cells originating in epithelia that make their way into the bloodstream and are found circulating in the in low numbers (less than 1 per 100 leukocytes) ${ }^{[95]}$. Depending on the tissue of origin, CTCs may present distinct morphological characteristics that vary according to cancer type and stage ${ }^{[94]}$. CTCs are usually found in clusters of tumor cells or associated to fibroblasts, leukocytes, and other endothelial cells, which increases the odds of colonizing distant tissues and originating 
metastasis ${ }^{[96]}$. Almost every type of solid tumor has been shown to be capable of shedding CTCs to the bloodstream and, thus, turning these CTCs into valuable biomarkers of disease progression ${ }^{[97]}$. As such, tremendous effort has been directed towards the development of analytical systems able to detect and isolate CTCs from whole blood. The majority of these platforms rely on the presence/absence of specific markers at the cell surface, such as epithelial cell adhesion molecule (EpCAM+), cytokeratin 8 (CK8+), and cytokeratin 19 (CK19+), among others ${ }^{[98]}$. For example, using these biomarkers, it was possible to detect metastatic breast cancer, where a level of 6-7 CTCs per $10 \mathrm{~mL}$ of blood correlated to poor survival ${ }^{[99]}$. However, sometimes, CTCs do not exhibit robust EpCAM expression at the surface and, as such, other antibodies targeting distinct cell surface markers may be used for capture and isolation of CTCs ${ }^{[100]}$.

Recent developments have simplified the procedures to retrieve CTCs from blood samples. For example, in 2007, Nagrath et al.$^{[101]}$ reported on a platform for capturing CTCs from whole blood via a microfluidic device, whose size might allow for point-of-care analysis. In the last years, there have been several attempts to develop integrated microfluidic devices for improved recovery of CTCs with higher purity by combining antibody assisted capture with size exclusion protocols ${ }^{[102]}$. For instance, a microfluidic chip for CTC isolation from blood-iChip-has been advertised that combines magnetic separation, hydrodynamic sorting, and inertial focusing of CTCs ${ }^{[103]}$.

PCR based protocols have allowed amplification of epithelial cell specific markers after the synthesis of cDNA from total RNA isolated from viable $\mathrm{CTCs}^{[104,105]}$. Critical information for improving diagnostics and clinical characterization in cancer patients can be retrieved from the molecular characterization of CTCs, e.g., expression level of gene drivers and single-cell profiling ${ }^{[106-113]}$. Several other biomarkers originating from CTCs have been used for more robust molecular profiling of cancer cells, such as single or multiplexed panels of microRNAs (miRNAs) ${ }^{[114,115]}$.

\section{miRNA}

miRNAs are small (19-24 bp) non-coding RNAs that play a critical role in post-transcriptional modulation of gene expression, whose role in cancer was elucidated at the beginning of the millennium ${ }^{[116-120]}$. The prognostic value of miRNAs in cancer has been highlighted in several studies. In 2005, Calin et al. ${ }^{[120]}$ showed for the first time the relevance of miRNAs for diagnostic and the correlation to prognostic. Subsequently, it was demonstrated that miRNAs were transcribed from cancer-related regions associated to DNA amplification, deletion, or translocation ${ }^{[121]}$. Another example is let-7, which, when expressed at lower levels in lung cancer patients, correlates to poor survival ${ }^{[122]}$. These pioneering studies highlighted the role of miRNA in cancer development and the value of assessing their expression for diagnosis and its correlation to prognosis ${ }^{[123]}$.

miRNAs are found in virtually all body fluids ${ }^{[124,125]}$. miRNAs are routinely detected in LB without noticeable changes in molecular and chemical stability ${ }^{[126-130]}$. In fact, miRNAs are extremely resilient to ribonucleases, which may be associated to their ability to bind plasma proteins, such as Argonaute 2 and high-density lipoprotein ${ }^{[131,132]}$. In addition, these miRNAs may be engulfed in secretory vesicles, including circulating exosomes and apoptotic bodies ${ }^{[128,133-135]}$ (see below). Selected plasma/serum circulating miRNAs could be used to discriminate cancer patients (e.g., breast ${ }^{[136]}$, colorectal ${ }^{[137]}$, gastric ${ }^{[138]}$, lung ${ }^{[139]}$, pancreatic $^{[140]}$, and hepatocellular ${ }^{[141]}$ ) from healthy individuals, making them excellent tools for earlier diagnosis.

In 2007, Caivano et al. ${ }^{[142]}$ showed that miRNA155 detected in from body fluids could be used as biomarker for the diagnostics and follow-up of hematologic malignancies through non-invasive biopsy approaches. Their results showed that miRNA155 levels in extracellular vesicles (EVs) were significantly higher in CLL, AML, and Waldenström's macroglobulinemia patients. They also found that miRNA155 levels in EVs were 
significantly lower in MDS and multiple myeloma. Moreover, high miRNA155 levels in EVs correlated to higher counts of white blood cell in AML patients.

Several approaches to analyze circulating miRNA levels have since emerged, including RT-qPCR, highthroughput microarrays, and, more recently, deep next generation sequencing (NGS) protocols ${ }^{[143]}$.

\section{Exosomes}

The intrinsic characteristics of exosomes make these vesicles suitable tumor biomarkers for LB. Exosomes are nanosized vesicles composed of a bi-lipidic membrane containing membrane proteins with a lumen composed of cytoplasmic proteins, RNAs, including mRNA and miRNAs, and others, such as cytokines or growth factors. Exosomes are formed in the endosomal pathway of eukaryotic cells and, thus, are highly enriched in proteins, such as tetraspanins, and adhesion molecules, such as integrins and cadherins ${ }^{[144]}$. Exosomes have an important role in cell-cell autocrine, paracrine, and endocrine communications and can be isolated from body fluids, such as plasma, urine, pericardial, pleural effusions, and amniotic fluid ${ }^{[145,146]}$.

In the cancer context, tumor cell derived exosomes have an active role in tumor progression, therapy invasion, and metastasis formation ${ }^{[147-152]}$. As exosomes content depends on the physiological state of the cell, the cargo and abundance of tumor derived exosomes generally reflects the stage of the tumor, rendering diagnostic value in LB for early tumor detection ${ }^{[153-155]}$. Even though exosomes are not being used in clinical practice, the potential of these vesicles for diagnosis is highlighted by the 71 clinical trials studies focused on exosomes of cancer patients (according to www.clinicalTrials.gov accessed on 12 September 2019), accompanied by the development of platforms for tumor derived exosomes detection in complex samples (e.g., surface plasmon resonance for exosome biomarkers detection ${ }^{[156]}$, microfluidic chip for ovarian cancer diagnosis ${ }^{[157]}$, or a platform with superparamagnetic conjunctions and molecular beacons targeting urinary exosomes for prostate cancer diagnosis ${ }^{[158]}$ ). Nevertheless, several sensitive and specific exosomal biomarkers were already suggested for early diagnosis of ovarian cancer (over-expression of miR200a, miR-200b, and miR200c in patient's serum exosomes) ${ }^{[159-161]}$, non-small cell lung cancer (enrichment of Leucine-rich $\alpha 2$-glycoprotein 1 in exosomes of patients urine and MALAT-1 in patient's blood) ${ }^{[162-164]}$, colon cancer (overexpression of miR-1246 and miR-23a in patient's serum exosomes) ${ }^{[165,166]}$, or pancreatic ductal adenocarcinoma (presence of glypican-1 in patient's serum) ${ }^{[167,168]}$. Regarding the metastatic potential of exosomes, it was described that presence of VEGF and PGF in exosomes could induce the initiation of the pre-metastatic niche at distant $\operatorname{sites}^{[169,170]}$ and the presence of specific integrins in the membrane of exosomes dictate internalization by a specific cell type, predicting organ of metastasis, e.g., exosomes expressing ITG $\alpha_{v} \beta_{5}$ bind specifically to Kupfer cells, defining liver tropism ${ }^{[171-173]}$.

The interest in the role of exosomes in liquid malignancies has been gaining momentum. As for the solid tumors, exosomes play important roles in progression and therapy resistance of lymphoma and leukemia ${ }^{[174,175]}$. For example, in CML, exosomes are active players in neo-angiogenesis at the bone marrow, possibly through exosome pro-angiogenic miRNAs-miR-92 and miR-126 $6^{[176-180]}$. The increase density and caliber of microvessels at the bone marrow of CML patients were suggested to be directly correlated with disease progression and poorer prognosis ${ }^{[181]}$.

\section{LB IN MYELOID MALIGNANCIES}

Conventional diagnostics of myeloid and/or lymphoid malignancies rely on full blood characterization with precise blood counts, complemented by morphologic examination of the bone marrow. Bone marrow aspirates are usually collected using a fine needle. Other samples include the removal of lymph node. All of these procedures are extremely disturbing for the patient since they are highly invasive ${ }^{[182]}$. Upon therapy, patient follow up requires a peripheral blood assessment every three months for morphological, cytogenetic, or molecular marker evaluation. The mounting evidence supporting the straightforward 
correlation between blood and biopsies in hematological malignancies has challenged the need for invasive procedures to retrieve information that is accessible via $\mathrm{LB}^{[182]}$. The discovery of CTCs and ctDNA has paved the way for non-invasive monitoring techniques. In fact, a peripheral blood sample allows screening CTCs, ctDNA, cfDNA, miRNAs, and vesicles (e.g., exosomes) ${ }^{[182]}$. In the next sections, we focus on the advantages of LB for myeloid malignancy management.

\section{LB in AML}

cfDNA mutational profiling in hematologic malignancies was performed for the first time in patients with $\mathrm{AML}$ and $\mathrm{MDS}^{[80]}$. Mutations in cfDNA were detected in $60 \%$ of patients, whereas these mutations were not present in DNA extracted from the respective paired peripheral blood or bone marrow. This fact reinforced the idea that plasma was an accessible and valuable material for diagnostics and monitoring of AML/ $\mathrm{MDS}^{[80]}$. More than 20 years later, it was revealed that blood of AML/MDS patients was enriched in tumor $\mathrm{DNA}^{[183]}$. Indeed, it is well known that cancer patients and, in particular AML patients, have elevated levels of cfDNA when compared to healthy individuals ${ }^{[184,185]}$. miRNAs seem to be a valuable biomarker in AML, since these small molecules are more abundant in the plasma from AML patients at diagnosis, when compared to healthy individuals. Interestingly, miRNA levels decrease after chemotherapy.

Another interesting element is that AML patients undergoing induction chemotherapy showed a reduction in circulating nucleosomal DNA fragments, but, in patients with complete remission, an initial rise in the cfDNA level was observed between Days 2 and 4 after induction chemotherapy, possibly due to increased apoptosis in response to treatment ${ }^{[186]}$.

A pilot study by Koutova et al ${ }^{[187]}$ in 2015 used plasma for characterization of miRNA signatures in AML patients (at diagnosis and in remission) that could be correlated to evolution following standard chemotherapy and before planned transplantation.

Analyzing cfDNA from peripheral blood and gDNA from bone marrow, it has also been demonstrated that Loss of Heterozygosity and chromosome $\mathrm{X}$ inactivation are the most frequent genetic abnormalities found in AML and MDS patients ${ }^{[183]}$. Data retrieved from this type of wide screening studies suggest that analysis of tumor derived cfDNA may replace bone marrow aspirated for screening genomic abnormalities.

In AML patients, cytogenetics is the starting point for full diagnostics characterization. Then, several gene markers have been used for the genetic molecular profiling. Nucleophosmin 1 (NPM1), Proto-oncogene C-KIT (C-KIT), CCAAT/enhancer binding protein alpha (CEBPA), and FMS related tyrosine kinase 3 (FLT3) are used for prognosis and direct therapeutic decisions following initial induction chemotherapy ${ }^{[188]}$. NPM1 is the most commonly mutated gene in AML and is therefore a valuable biomarker of disease ${ }^{[189,190]}$. Quan et al. ${ }^{[189]}$ used cfDNA from AML patients to analyze the number of copies and mutations in NPM1 by qPCR and NGS, respectively. The mutation profile of NPM1 correlated directly with different subtypes of AML. Cytogenetic and particular molecular profiles found in cfDNA of patients with myeloid disorders seem to be suitable towards molecular profiling that provides the necessary information for optimized prognosis and treatment decisions.

Recently, Nakamura and co-workers demonstrated, for the first time, that non-invasive ctDNA screening was comparable to bone marrow analysis towards identification of patients at high risk for relapse in MDS and AML following allo-HSCT ${ }^{[191]}$. Additionally, this study also demonstrated that serum ctDNA may be used for assessing minimal residual disease in AML and MDS following allo-HSCT and, thus, may alleviate patients from frequent bone marrow punctures. 


\section{LB in MDS}

Bone marrow biopsy is the standard protocol for genetic and epigenetic characterization in MDS. However, this is a complicated procedure that is not always easy to perform and/or feasible ${ }^{[50]}$. In these situations, cfDNA would represent a better and less painful alternative to determine the tumor status, allowing for detection of genetic mutations and methylation status of CpG islands in MDS patients by pyrosequencing ${ }^{[192]}$. More recently, detection of specific mutations in cfDNA using PCR and direct sequencing of several loci was also achieved, demonstrating the wide range of application of cfDNA in MDS characterization ${ }^{[193]}$. Yeh et al ${ }^{[194]}$ evaluated cfDNA as a minimally invasive material for the genetic profiling of MDS patients using a panel of 55 genes previously demonstrated to be involved in cancer onset and development. These findings suggest that cfDNA can provide comparable molecular information to bone marrow biopsy, which might be extremely useful when bone marrow biopsy cannot be performed.

\section{LB in CML}

The use of LB has not been thoroughly explored in CML. Nonetheless, exosomes retrieved from blood of CML patients contain amphiregulin, an inducer of EGFR activation in stromal cells located in the bone marrow that might be used as biomarker ${ }^{[195]}$. In turn, stromal cells activated via EGFR increase the secretion of IL-8, which then stimulates the proliferation of CML cells ${ }^{[195]}$. As such, these molecular markers may be used to evaluate the different stages of tumor cell evolution. It must be noted that the majority of studies focusing on CML have been performed using CML cell lineages, i.e., cell models, and validation of data in real patient samples still needs to be performed. Nevertheless, it has been shown that exosomes secreted by CML cells play a critical role in the formation of new vessels, perhaps even have a pivotal responsibility for neo-angiogenesis in the bone marrow of CML patients ${ }^{[176-180,195,196]}$, and thus could be useful as surrogate markers for disease evolution. Several key molecules thought to play a role in angiogenesis have been identified within exosomes derived from CML, such as the pro-angiogenic miRNA92 and miRNA126 ${ }^{[176,179]}$. Moreover, it has been demonstrated that exosomes derived from K562 cells are able to induce angiotube formation in human umbilical vein endothelial cells (HUVEC) ${ }^{[178]}$. In addition, exosomes secreted by LAMA84 CML cells induced expression of IL-8 in HUVEC ${ }^{[180]}$. Altogether, these preliminary efforts seem to indicate the value of exosomes retrieved from LB in diagnostics and prognostics in CML.

\section{THE NEXT STEP IN LB IN LEUKEMIA}

The growing interest in LB as a less invasive approach to retrieve valuable molecular information of malignancies, and thus more convenient for patients, has prompted the development of multiple clinical trials to evaluate LB as prognostic and predictive biomarkers (https://clinicaltrials.gov/). Table 1 highlights some of the most relevant clinical trials evaluating the possible use of LB in myeloid malignancies. It should be noted that there are more than 220 currently ongoing clinical trials focusing on LB in all types of cancer, demonstrating the importance of LB in cancer management.

Some of these clinical trials are directed at the critical points herein discussed. For example, iCARE (NCT03138395) focuses on the need to provide follow-up in patients undergoing chemotherapy. In fact, not achieving minimal residual disease following chemotherapy might be a critical predictor of refractory disease and seems to be associated with the death of $20 \%$ of AML and $80 \%$ of MDS patients. iCARE addresses an important issue that concerns the use of droplet digital PCR (ddPCR) for quantitative mutant allele frequency (MAF) in plasma for MDS and AML patients before, during, and after chemotherapy treatment. This approach may bring evidence of the important role of non-invasive means of monitorization in phase II and III clinical trials of new therapeutic agents, and cancer progression, providing clinicians with an opportunity to intervene before patients relapse. This clinical trial has been withdrawn based on the need of collecting specimens from a bank that will require approval of an additional protocol for institutional review board, which highlights the need for standardized sample collection protocols for LB. 





Clinical trials UMIN000033003 and NCT01541800 address ctDNA and miRNAs in LB, respectively, as a mean of following relapse and prognosis in leukemia patients. For cfDNA, genome-wide copy number evaluation from plasma via shallow or low-coverage sequencing of cfDNA is scalable and costeffective $^{[197-201]}$ and has recently been shown to be highly prognostic ${ }^{[201]}$.

LB show several advantages for cancer management strategies, such as: (1) minimally invasiveness; (2) better reproduction of the patients' genetic mutations profile; (3) suitability as companion diagnostics; and (4) sample collection decreases the possibility of contamination with unwanted tissue/cells. Because LB is less invasive, it may be used more recurrently with less negative impact for patients than conventional biopsies $^{[202]}$. Additionally, mounting evidence shows that LB deliver better portrait of the genomic context of the tumor through time, which may be of extreme valuable as companion diagnostics with the possibility to screen for the time dependence evolution of mutations ${ }^{[203]}$. LB further advantages over conventional tissue biopsies include the possibility of becoming a source of fresh tumor-derived material that are free from contamination (e.g., chemical preservatives) ${ }^{[203]}$. The application of LB to follow and assess solid tumors has been clearly demonstrated, whose advantages over tissue biopsies have been thoroughly documented. Newman and co-workers evaluated the performance of LBs as starting material for the screening of genomic mutations and evaluation of disease burden by quantifying cfDNA levels. The molecular data retrieved from these assessments were compared to whole body imaging screens via positron-emission tomography and computed tomography, which showed that lower levels of cfDNA in the plasma correlated with better clinical prognostics ${ }^{[204]}$.

There are also some limitations to the widespread utilization of LB. It should be noted that LB might be less efficacious for detecting rare variants at very low frequency. In addition, LBs may be able to assess tumor heterogeneity and identify which clones dominate at a particular colonization site, but combining them with standard solid biopsies clearly improves the robustness of information. Because different clones at different sites will release ctDNA at distinct rates, LBs may introduce an undesired bias into the quantitative molecular characterization of the tumor evolution. For example, brain metastases usually release little to no ctDNA into circulation ${ }^{[53]}$. This is particularly relevant when considering the assessment of minimal disease and/or resistance of a few clonal cells to therapeutics, where extremely high sensitivity is usually desirable.

In addition, several studies have highlighted the differences in cfDNA levels derived from distinct tumor types and between body fluids used for analysis ${ }^{[205-207]}$. The amount of cfDNA derived from a particular tumor correlates with the cancer stage, degree of vascularization, metastatic potential, and apoptosis rate $^{[206,208]}$. In some cases, tumor-derived cfDNA may be lower than $1 \%$ of the total circulating DNA, which may not allow for retrieving the full picture required for effective management of the patient in hand. In addition, identification and characterization of mutations requires extensive validation of processes and protocols so as to ensure clinically relevant data ${ }^{[205,207]}$.

\section{CONCLUSION}

Early detection of cancer is critical for improving the chances of therapeutic intervention and enhance the overall survival rates. Tumor detection is confirmed by traditional tissue biopsy. Due to their invasiveness, issue biopsies show potential harmful effects on the patient wellbeing with several complications, they are sometimes impossible to repeat over time, and, in some clinical conditions, they are impossible to obtain when the tumor is inaccessible. As such, oncologists have been focusing on cancer-derived material in the blood, which are easier to access and collect with less impact to the patient. LB relying on CTCs, ctDNA, miRNA, and EXOs are at the core of innovative approaches to retrieve relevant information on the molecular aspects of the tumor, offering a range of information that allows functional studies, and with the potential for diagnostics and management of myeloid malignancies, including MDS, AML, and 
CML. Innovative technology platforms have allowed the combination of standard molecular profiling with LB into integrated systems for biomarker capture and analysis. However, CTCs, ctDNA, and EXOs are usually recovered in small concentrations from samples, negatively impacting the analytical output in terms of specificity and sensitivity. Current high-throughput platforms often provide data that are not easy to reproduce across laboratories, highlighting the need for standardization of procedures for collection and processing of LBs in clinical context, together with the analytical validation of the protocols when utilizing LB.

\section{DECLARATIONS}

\section{Authors' contributions}

Drafted the manuscritp: Abdulmawjood B, Roma-Rodrigues C

Outlined the concept and content: Fernandes AR, Baptista PV

Wrote adn edited the manuscript: Abdulmawjood B, Roma-Rodrigues C, Fernandes AR, Baptista PV

\section{Availability of data and materials}

Not applicable.

\section{Financial support and sponsorship}

This work was supported by the Applied Molecular Biosciences Unit-UCIBIO which is financed by national funds from FCT/MCTES (UID/Multi/04378/2019).

\section{Conflicts of interest}

All authors declared that there are no conflicts of interest.

\section{Ethical approval and consent to participate}

Not applicable.

\section{Consent for publication}

Not applicable.

\section{Copyright}

(c) The Author(s) 2019.

\section{REFERENCES}

1. Siegel RL, Miller KD, Jemal A. Cancer statistics, 2016. CA Cancer J Clin 2016;66:7-30.

2. $\mathrm{Hu} \mathrm{D}$, Shilatifard A. Epigenetics of hematopoiesis and hematological malignancies. Genes Dev 2016;30:2021-41.

3. Fleming D. Leukemia: understanding it's types and treatments. Oncol Nurs Advisor 2012;15-20.

4. Smeltzer SC, Bare BG, Hinkle JL, Cheever K H. Textbook of medical surgical nursing. 11th edition. Philadelphia: Lippincott Williams \& Wilkins; 2008. pp. 410-22.

5. “Types of Leukemia.” What You Need To Know About Leukemia. National Cancer Institute, 3 Dec. 2013. Web. 24 Apr. 2014. Available from: https://www.cancer.gov/types/leukemia/hp. [Last accessed on 16 Dec 2019]

6. Bain BJ. Leukaemia Diagnosis. Oxford: John Wiley \& Sons; 2010. pp. 1-63.

7. Ciesla B. Hematology in Practice. Philadelphia: F.A. Davis Co; 2007. pp. 167-202.

8. Ball ED. 100 Questions \& Answers about Leukemia. Sudbury: Jones \& Bartlett Publishers; 2002. pp. 1-34.

9. Bain B. Leukaemia diagnosis. Third edition. Oxford: John Wiley \& Sons; 2003. pp. 57-143.

10. Bain B. Blood Cells: A Practical Guide. Fourth edition. Chichester: Published by WileyBlackwell; 2006. pp. 416-80.

11. Norman B. Diagnostic Hematology. 1st edition. London: Springer; 2009. pp. 9-79.

12. Foran JM, Shammo JM. Clinical presentation, diagnosis, and prognosis of myelodysplastic syndromes. Am J Med $2012 ; 125$ (7 Suppl):S6-13.

13. Barzi A, Sekeres MA. Myelodysplastic syndromes: a practical approach to diagnosis and treatment. Cleve Clin J Med 2010;77:37-44.

14. Sharma SK, Gupta S, Seth T, Mishra P, Mahapatra M, et al. Leukemia cutis: an unusual presentation. Indian J Hematol Blood Transfus 2012;28:175-7.

15. Rao AG, Danturty I. Leukemia cutis. Indian J Dermatol 2012;57:504. 
16. Juliusson G, Antunovic P, Derolf A, Lehmann S, Möllgård L, et al. Age and acute myeloid leukemia: real world data on decision to treat and outcomes from the Swedish Acute Leukemia Registry. Blood 2009;113:4179-87.

17. Juliusson G, Lazarevic V, Hörstedt AS, Hagberg O, Höglund M; Swedish Acute Leukemia Registry Group. Acute myeloid leukemia in the real world: why population based registries are needed. Blood 2012;119:3890-9.

18. Bennett JM, Catovsky D, Daniel MT, Flandrin G, Galton DA, et al. Proposals for the classification of the acute leukaemias. FrenchAmerican-British (FAB) co-operative group. Br J Haematol 1976;33:451-8.

19. Dohner H, Weisdorf DJ, Bloomfield CD. Acute myeloid leukemia. N Engl J Med 2015;373:1136-1152.

20. Grimwade D, Hills RK, Moorman AV, Walker H, Chatters S, et al.; National Cancer Research Institute Adult Leukaemia Working Group. Refinement of cytogenetic classification in acute myeloid leukemia: determination of prognostic significance of rare recurring chromosomal abnormalities among 5876 younger adult patients treated in the United Kingdom Medical Research Council trials. Blood 2010;116:354-65.

21. Estey EH. Acute myeloid leukemia: 2012 update on diagnosis, risk stratification, and management. Am J Hematol 2012;87:89-99.

22. Höglund M, Sandin F, Simonsson B. Epidemiology of chronic myeloid leukaemia: an update. Ann Hematol 2015;94:S241-7.

23. Jabbour E, Kantarjian H. Chronic myeloid leukemia: 2018 update on diagnosis, therapy and monitoring. Am J Hematol 2018;93:442-59.

24. Deininger MW, Goldman JM, Melo JV. The molecular biology of chronic myeloid leukemia. Blood 2000;96:3343-56.

25. Lugo TG, Pendergast AM, Muller AJ, Witte ON. Tyrosine kinase activity and transformation potency of bcr-abl oncogene products. Science 1990;247:1079-82.

26. Faderl S, Talpaz M, Estrov Z, O’Brien S, Kurzrock R, et al. The biology of chronic myeloid leukemia. N Engl J Med 1999;341:164-72.

27. Sawyers CL. Chronic myeloid leukemia. N Eng1 J Med 1999;340:133040.

28. Geary CG. The story of chronic myeloid leukaemia. Br J Haematol 2000;110:2-11.

29. Baccarani M, Castagnetti F, Gugliotta G, Palandri F, Rosti G. Treatment - recommendations for chronic myeloid leukemia. Mediterr J Hematol Infect Dis 2014;6:e2014005.

30. Fefer A, Cheever MA, Thomas ED, Boyd C, Ramberg R, et al. Disappearance of Ph1-positive cells in four patients with chronic granulocytic leukemia after chemotherapy, irradiation and marrow transplantation from an identical twin. N Engl J Med 1979;300:333-7.

31. Goldman JM, Baughan AS, McCarthy DM, Worsley AM, Hows JM, et al. Marrow transplantation for patients in the chronic phase of chronic granulocytic leukaemia. Lancet 1982;2:623-5.

32. Speck B, Bortin MM, Champlin R, Goldman JM, Herzig RH, et al. Allogeneic bone-marrow transplantation for chronic myelogenous leukaemia. Lancet 1984;1:665-8.

33. Talpaz M, McCredie KB, Mavligit GM, Gutterman JU. Leukocyte interferon-induced myeloid cytoreduction in chronic myelogenous leukemia. Blood 1983;62:689-92.

34. Hochhaus A, O’Brien SG, Guilhot F, Druker BJ, Branford S, et al. Six-year follow-up of patients receiving imatinib for the first-line treatment of chronic myeloid leukemia. Leukemia 2009;23:1054-61.

35. Druker BJ, Guilhot F, O’Brien SG, Gathmann I, Kantarjian H, et al. Five-year follow-up of patients receiving imatinib for chronic myeloid leukemia. N Engl J Med 2006;355:2408-17.

36. Cortes J, Kantarjia H. Chronic myeloid leukemia: sequencing of TKI therapies. Hematology Am Soc Hematol Educ Program 2016;2016:164-9.

37. Neukirchen J, Schoonen WM, Strupp C, Gattermann N, Aul C, et al. Incidence and prevalence of myelodysplastic syndromes: data from the Düsseldorf MDS-registry. Leuk Res 2011;35:1591-6.

38. Williamson PJ, Kruger AR, Reynolds PJ, Hamblin TJ, Oscier DG. Establishing the incidence of myelodysplastic syndrome. Br J Haematol 1994;87:743-5.

39. Kuendgen A, Strupp C, Aivado M, Hildebrandt B, Haas R, et al. Myelodysplastic syndromes in patients younger than age 50. J Clin Oncol 2006;24:5358-65.

40. Geyh S, Oz S, Cadeddu RP, Fröbel J, Brückner B, et al. Insufficient stromal support in MDS results from molecular and functional deficits of mesenchymal stromal cells. Leukemia 2013;27:1841-51.

41. Germing U, Gattermann N, Strupp C, Aivado M, Hossfeld DK, et al. Myelodysplastische syndrome: neue WHO-klassifikation und aspekte zur pathogenese, prognose and therapie. Dtsch Arztebl 2001;98:A2272-8.

42. Germing U, Aul C, Niemeyer CM, Haas R, Bennett JM. Epidemiology, classification and prognosis of adults and children with myelodysplastic syndromes. Ann Hematol 2008;87:691-9.

43. Greenberg P, Cox C, LeBeau MM, Fenaux P, Morel P, et al. International scoring system for evaluating prognosis in myelodysplastic syndromes. Blood 1997;89:2079-88.

44. Greenberg PL, Tuechler H, Schanz J, Sanz G, Garcia-Manero G, et al. Revised international prognostic scoring system for myelodysplastic syndromes. Blood 2012;120:2454-65.

45. Arber DA, Orazi A, Hasserjian R, Thiele J, Borowitz MJ, et al. The 2016 revision to the World Health Organization classification of myeloid neoplasms and acute leukemia. Blood 2016;127:2391-405.

46. Diamantis A, Magiorkinis E, Koutselini H. Fine-needle aspiration (FNA) biopsy: historical aspects. Folia Histochem. Cytobiol 2009;47:191-7.

47. Crowley E, Di Nicolantonio F, Loupakis F, Bardelli A. Liquid biopsy: monitoring cancergenetics in the blood. Nat Rev Clin Oncol 2013;10:472-84.

48. Perakis S, Speicher MR. Emerging concepts in liquid biopsies. BMC Med 2017;15:75

49. Siravegna G, Marsoni S, Siena S, Bardelli A. Integrating liquid biopsies into the management of cancer. Nat Rev Clin Oncol $2017 ; 14: 531-48$

50. Kubaczkova V, Vrabel D, Sedlarikova L, Besse L, Sevcikova S. Cell- free DNA - Minimally invasive marker of hematological malignancies. Eur J Haematol 2017;99:291-9. 
51. Buder A, Tomuta C, Filipits M. The potential of liquid biopsies. Curr Opin Oncol 2016;28:130-4.

52. Rolfo C, Castiglia M, Hong D, Alessandro R, Mertens I, et al. Liquid biopsies in lung cancer: the new ambrosia of researchers. Biochim Biophys Acta 2014;1846:539-46.

53. Domínguez-Vigil I, Moreno-Martínez A, Wang J, Roehrl M, Barrera-Saldaña H. The dawn of the liquid biopsy in the fight against cancer. Oncotarget 2018;9:2912-22.

54. Bettegowda C, Sausen M, Leary R, Kinde I, Wang Y, et al. Detection of circulating tumor DNA in early- and late-stage human malignancies. Sci Transl Med 2014;6:224ra24.

55. Zheng D, Ye X, Zhang MZ, Sun Y, Wang JY, et al. Plasma EGFR T790M ctDNA status is associated with clinical outcome in advanced NSCLC patients with acquired EGFR-TKI resistance. Sci Rep 2016;6:20913.

56. Novello S, Barlesi F, Califano R, Cufer T, Ekman S, et al. Metastatic non-small-cell lung cancer: ESMO Clinical Practice Guidelines for diagnosis, treatment and follow-up. Ann Oncol 2016;27:v1-v27.

57. Diaz LA, Bardelli A. Liquid biopsies: genotyping circulating tumor DNA. J Clin Oncol 2014;32:579-86.

58. Stroun M, Lyautey J, Lederrey C, Olson-Sand A, Anker P. About the possible origin and mechanism of circulating DNA apoptosis and active DNA release. Clin Chim Acta 2001;313:139-42.

59. Jahr S, Hentze H, Englisch S, Hardt D, Fackelmayer FO, et al. DNA fragments in the blood plasma of cancer patients: quantitations and evidence for their origin from apoptotic and necrotic cells. Cancer Res 2001;61:1659-65.

60. Mouliere F, Robert B, Arnau Peyrotte E, Del Rio M, Ychou M, et al. High fragmentation characterizes tumour-derived circulating DNA. PLoS One 2011;6:e23418.

61. Bergsmedh A, Szeles A, Henriksson M, Bratt A, Folkman MJ, et al. Horizontal transfer of oncogenes by uptake of apoptotic bodies. Proc Natl Acad Sci U S A 2001;98:6407-11.

62. Underhill HR, Kitzman JO, Hellwig S, Welker NC, Daza R, et al. Fragment length of circulating tumor DNA. PLoS Genet 2016;12:e1006162.

63. Cheng F, Su L, Qian C. Circulating tumor DNA: a promising biomarker in the liquid biopsy of cancer. Oncotarget 2016;7:48832-41.

64. Li J, Dittmar RL, Xia S, Zhang H, Du M, et al. Cell-free DNA copy number variations in plasma from colorectal cancer patients. Mol Oncol 2017;11:1099-111.

65. Soave A, Chun FK, Hillebrand T, Rink M, Weisbach L, et al. Copy number variations of circulating, cell-free DNA in urothelial carcinoma of the bladder patients treated with radical cystectomy: a prospective study. Oncotarget 2017;8:56398-407.

66. Husain H, Nykin D, Bui N, Quan D, Gomez G, et al. Cell-free DNA from ascites and pleural effusions: molecular insights into genomic aberrations and disease biology. Mol Cancer Ther 2017;16:948-55.

67. Li Z, Guo X, Tang L, Peng L, Chen M, et al. Methylation analysis of plasma cell-free DNA for breast cancer early detection using bisulfite next-generation sequencing. Tumour Biol 2016;37:13111-9.

68. Fleischhacker M, Schmidt B. Circulating nucleic acids (CNAs) and cancer-A survey. Biochim Biophys Acta 2007;1775:181-232.

69. Siravegna G, Bardelli A. Genotyping cell-free tumor DNA in the blood to detect residual disease and drug resistance. Genome Biol 2014;15:449.

70. Schwarzenbach H, Hoon DS, Pantel K. Cell-free nucleic acids as biomarkers in cancer patients. Nat Rev Cancer 2011;11:426-37.

71. Chan KC, Yeung SW, Lui WB, Rainer TH, Lo YM. Effects of preanalytical factors on the molecular size of cell-free DNA in blood. Clin Chem 2005;51:781-4.

72. Su YH, Wang M, Aiamkitsumrit B, Brenner DE, Block TM. Detection of a K-ras mutation in urine of patients with colorectal cancer. Cancer Biomark 2005;1:177-82.

73. Wang Y, Springer S, Mulvey CL, Silliman N, Schaefer J, et al. Detection of somatic mutations and HPV in the saliva and plasma of patients with head and neck squamous cell carcinomas. Sci Transl Med 2015;7:293ra104.

74. De Mattos-Arruda L, Mayor R, Ng CK, Weigelt B, Martínez-Ricarte F, et al. Cerebrospinal fluid-derived circulating tumour DNA better represents the genomic alterations of brain tumours than plasma. Nat Commun 2015;6:8839.

75. Barra GB, Santa Rita TH, de Almeida Vasques J, Chianca CF, Nery LF, et al. EDTA-mediated inhibition of DNases protects circulating cell-free DNA from ex vivo degradation in blood samples. Clin Biochem 2015;48:976-81.

76. EI Messaoudi S, Rolet F, Mouliere F, Thierry AR. Circulating cell free DNA: preanalytical considerations. Clin Chim Acta 2013;424:222-30.

77. Parpart-Li S, Bartlett B, Popoli M, Adleff V, Tucker L, et al. The effect of preservative and temperature on the analysis of circulating tumor DNA. Clin Cancer Res 2017;23:2471-7.

78. Mandel P, Metais P. Les acides nucléiques du plasma sanguin chez l'homme. C R Seances Soc Biol Fil 1948;142:241-3. (in French)

79. Leon SA, Shapiro B, Sklaroff DM, Yaros MJ. Free DNA in the serum of cancer patients and the effect of therapy. Cancer Res 1977;37:646-50.

80. Vasioukhin V, Anker P, Maurice P, Lyautey J, Lederrey C, et al. Point mutations of the N- ras gene in the blood plasma DNA of patients with myelodysplastic syndrome or acute myelogenous leukaemia. Br J Haematol 1994;86:774-9.

81. Osborne CM, Hardisty E, Devers P, Kaiser-Rogers K, Hayden MA, et al. Discordant noninvasive prenatal testing results in a patient subsequently diagnosed with metastatic disease. Prenat Diagn 2013;33:609-11.

82. Cell-free DNA screening for fetal aneuploidy. Obs Gynecol 2015;126:e31-7.

83. Heitzer E, Ulz P, Geigl JB. Circulating tumor DNA as a liquid biopsy for cancer. Clin Chem 2015;61:112-23.

84. Marzese DM, Hirose H, Hoon DSB. Diagnostic and prognostic value of circulating tumor-related DNA in cancer patients. Expert Rev Mol Diagn 2013;13:827-44.

85. Han X, Wang J, Sun Y. Circulating tumor DNA as biomarkers for cancer detection. Genomics Proteomics Bioinformatics 2017;15:59-72.

86. Martinez-Galan J, Torres-Torres B, Nunez L-PJ, Del Moral R, Ruiz De Almodovar J, et al. ESR1 gene promoter region methylation in free circulating DNA and its correlation with estrogen receptor protein expression in tumor tissue in breast cancer patients. BMC 
Cancer 2014;14:59.

87. Church TR, Wandell M, Lofton-Day C, Mongin SJ, Burger M, et al. Prospective evaluation of methylated SEPT9 in plasma for detection of asymptomatic colorectal cancer. Gut 2014;63:317-25.

88. Cohen JD, Li L, Wang Y, Thoburn C, Afsari B, et al. Detection and localization of surgically resectable cancers with a multi-analyte blood test. Science 2018;359:926-30.

89. Stevenson K, Lawrence MS, Sougnez C, Stewart C, Sivachenko A, et al. Evolution and impact of subclonal mutations in chronic lymphocytic leukemia. Cell 2013;152:714-26.

90. Abbosh C, Birkbak NJ, Wilson GA, Jamal-Hanjani M, Constantin T, et al. Phylogenetic ctDNA analysis depicts early stage lung cancer evolution. Nature 2017;545:446-51.

91. Imamura T, Komatsu S, Ichikawa D, Kawaguchi T, Miyamae M, et al. Liquid biopsy in patients with pancreatic cancer: circulating tumor cells and cell-free nucleic acids. World J Gastroenterol 2016;22:5627-41.

92. Morgan CD. Observations on cancer: its pathology, and its relations to the organism and to other morbid growths. Lancet 1874; $103: 325-9$

93. Ashworth T. A case of cancer in which cells similar to those in the tumors were seen in the blood after death. Aust Med J 1869;14:146-7.

94. Parkinson DR, Dracopoli N, Petty BG, Compton C, Cristofanilli M, et al. Considerations in the development of circulating tumor cell technology for clinical use. J Transl Med 2012;10:138.

95. Young R, Pailler E, Billiot F, Drusch F, Barthelemy A, et al. Circulating tumor cells in lung cancer. Acta Cytol 2012;56:655-60.

96. Krebs MG, Metcalf RL, Carter L, Brady G, Blackhall FH, et al. Molecular analysis of circulating tumour cellsbiology and biomarkers. Nat Rev Clin Oncol 2014;11:129-44.

97. Lianidou ES, Strati A, Markou A. Circulating tumor cells as promising novel biomarkers in solid cancers. Crit Rev Clin Lab Sci 2014;51:160-71.

98. De Wit S, van Dalum G, Terstappen LW. Detection of circulating tumor cells. Scientifica 2014;2014:819362.

99. Hayes DF, Cristofanilli M, Budd GT, Ellis MJ, Stopeck A, et al. Circulating tumor cells at each follow-up time point during therapy of metastatic breast cancer patients predict progression-free and overall survival. Clin Cancer Res 2006;12:4218-24.

100. Alix-Panabières C, Pantel K. Circulating tumor cells: liquid biopsy of cancer. Clin Chem 2013;59:110-8.

101. Nagrath S, Sequist LV, Maheswaran S, Bell DW, Irimia D, et al. Isolation of rare circulating tumour cells in cancer patients by microchip technology. Nature 2007;450:1235-9.

102. Marrugo-Ramírez J, Mir M, Samitier J. Blood-based cancer biomarkers in liquid biopsy: a promising non-invasive alternative to tissue biopsy. Int J Mol Sci 2018;19:2877

103. Ozkumur E, Shah AM, Ciciliano JC, Emmink BL, Miyamoto DT, et al. Inertial focusing for tumor antigen-dependent and-independent sorting of rare circulating tumor cells. Sci Transl Med 2013;5:179ra47.

104. Lianidou ES. Gene expression profiling and DNA methylation analyses of CTCs. Mol Oncol 2016;10:431-42.

105. Lianidou ES, Markou A. Molecular assays for the detection and characterization of CTCs. Recent Results Cancer Res 2012;195:111-23.

106. Markou A, Lazaridou M, Paraskevopoulos P, Chen S, Świerczewska M, et al. Multiplex gene expression profiling of in vivo isolated circulating tumor cells in high risk prostate cancer patients. Clin Chem 2018;64:297-306.

107. Strati A, Koutsodontis G, Papaxoinis G, Angelidis I, Zavridou M, et al. Prognostic significance of PD-L1 expression on circulating tumor cells in patients with head and neck squamous cell carcinoma. Ann Oncol 2017;28:1923-33.

108. Keup C, Mach P, Aktas B, Tewes M, Kolberg HC, et al. RNA profiles of circulating tumor cells and extracellular vesicles for therapy stratification of metastatic breast cancer patients. Clin Chem 2018;64:1054-62.

109. König L, Kasimir-Bauer S, Bittner A-K, Hoffmann O, Wagner B, et al. Elevated levels of extracellular vesicles are associated with therapy failure and disease progression in breast cancer patients undergoing neoadjuvant chemotherapy. Oncoimmunology 2017;7:e1376153.

110. Bredemeier M, Edimiris P, Mach P, Kubista M, Sjöback R, et al. Gene expression signatures in circulating tumor cells correlate with response to therapy in metastatic breast cancer. Clin Chem 2017;63:1585-93.

111. Chebouti I, Kasimir-Bauer S, Buderath P, Wimberger P, Hauch S, et al. EMT-like circulating tumor cells in ovarian cancer patients are enriched by platinum-based chemotherapy. Oncotarget 2017;8:48820-31.

112. Reijm EA, Sieuwerts AM, Smid M, Vries JB, Mostert B, et al. An 8-gene mRNA expression profile in circulating tumor cells predicts response to aromatase inhibitors in metastatic breast cancer patients. BMC Cancer 2016;16:123.

113. Gorges TM, Kuske A, Röck K, Mauermann O, Müller V, et al. Accession of tumor heterogeneity by multiplex transcriptome profiling of single circulating tumor cells. Clin Chem 2016;62:1504-15.

114. Markou A, Zavridou M, Sourvinou I, Yousef G, Kounelis S, et al. Direct comparison of metastasis-related miRNAs expression levels in circulating tumor cells, corresponding plasma, and primary tumors of breast cancer patients. Clin Chem 2016;62:1002-11.

115. Sieuwerts AM, Kraan J, Bolt-de Vries J, van der Spoel P, Mostert B, et al. Molecular characterization of circulating tumor cells in large quantities of contaminating leukocytes by a multiplex real-time PCR. Breast Cancer Res Treat 2009;118:455-68.

116. Frontela Noda M. MicroRNAs in cancer: from research to clinical practice. Rev Cubana Med 2012;51:325-35. (in Spanish)

117. Etheridge A, Lee I, Hood L, Galas D, Wang K. Extracellular microRNA: a new source of biomarkers. Mutat Res 2011;717:85-90.

118. Resnick KE, Alder H, Hagan JP, Richardson DL, Croce CM, et al. The detection of differentially expressed microRNAs from the serum of ovarian cancer patients using a novel real-time PCR platform. Gynecol Oncol 2009;112:55-9.

119. Calin GA, Dumitru CD, Shimizu M, Bichi R, Zupo S, et al. Frequent deletions and down-regulation of micro-RNA genes miR15 and miR16 at 13q14 in chronic lymphocytic leukemia. Proc Natl Acad Sci U S A 2002;99:15524-9.

120. Calin GA, Ferracin M, Cimmino A, Di Leva G, Shimizu M, et al. A microRNA signature associated with prognosis and progression in chronic lymphocytic leukemia. N Engl J Med 2005;353:1793-801.

121. Croce CM. Causes and consequences of microRNA dysregulation in cancer. Nat Rev Genet 2009;10:704-14. 
122. Takamizawa J, Konishi H, Yanagisawa K, Tomida S, Osada H, et al. Reduced expression of the let-7 microRNAs in human lung cancers in association with shortened postoperative survival. Cancer Res 2004;64:3753-6.

123. Kasinski AL, Slack FJ. Epigenetics and genetics. MicroRNAs en route to the clinic: progress in validating and targeting microRNAs for cancer therapy. Nat Rev Cancer 2011;11:849-64.

124. Weber JA, Baxter DH, Zhang SL, Huang DY, Huang KH, et al. The MicroRNA spectrum in 12 body fluids. Clin Chem 2010;56:1733-41.

125. Wang K, Yuan Y, Cho JH, McClarty S, Baxter D, et al. Comparing the MicroRNA spectrum between serum and plasma. PloS One 2012;7:e41561.

126. Calin GA, Croce CM. MicroRNA signatures in human cancers. Nat Rev Cancer 2006;6:857-66.

127. Mitchell PS, Parkin RK, Kroh EM, Fritz BR, Wyman SK, et al. Circulating microRNAs as stable blood-based markers for cancer detection. Proc Natl Acad Sci U S A 2008;105:10513-8.

128. Chen X, Ba Y, Ma L, Cai X, Yin Y, et al. Characterization of microRNAs in serum: a novel class of biomarkers for diagnosis of cancer and other diseases. Cell Res 2008;18:997-1006.

129. Filipowicz W, Bhattacharyya SN, Sonenberg N. Mechanisms of post-transcriptional regulation by microRNAs: are the answers in sight? Nat Rev Genet 2008;9:102-14.

130. Ichikawa D, Komatsu S, Konishi H, Otsuji E. Circulating microRNA in digestive tract cancers. Gastroenterology 2012;142:1074-8. e1071.

131. Arroyo JD, Chevillet JR, Kroh EM, Ruf IK, Pritchard CC, et al. Argonaute2 complexes carry a population of circulating microRNAs independent of vesicles in human plasma. Proc Natl Acad Sci USA 2011;108:5003-8.

132. Vickers KC, Palmisano BT, Shoucri BM, Shamburek RD, Remaley AT. MicroRNAs are transported in plasma and delivered to recipient cells by high-density lipoproteins. Nat Cell Biol 2011;13:423-33.

133. Kosaka N, Iguchi H, Ochiya T. Circulating microRNA in body fluid: a new potential biomarker for cancer diagnosis and prognosis. Cancer Sci 2010;101:2087-92.

134. Hasselmann DO, Rappl G, Tilgen W, Reinhold U. Extracellular tyrosinase mRNA within apoptotic bodies is protected from degradation in human serum. Clin Chem 2001;47:1488-9.

135. Cocucci E, Racchetti G, Meldolesi J. Shedding microvesicles: artefacts no more. Trends Cell Biol 2009;19:43-51.

136. Antolin S, Calvo L, Blanco-Calvo M, Santiago MP, Lorenzo-Patino MJ, et al. Circulating miR-200c and miR-141 and outcomes in patients with breast cancer. BMC Cancer 2015;15:297.

137. Zanutto S, Pizzamiglio S, Ghilotti M, Bertan C, Ravagnani F, et al. Circulating miR-378 in plasma: a reliable, haemolysis-independent biomarker for colorectal cancer. Br J Cancer 2014;110:1001-7.

138. Zhang J, Song Y, Zhang C, Zhi X, Fu H, et al. Circulating MiR16-5p and MiR-19b-3p as two novel potential biomarkers to indicate progression of gastric cancer. Theranostics 2015;5:733-45.

139. Zhao Y, Song Y, Yao L, Song G, Teng C. Circulating microRNAs: promising biomarkers involved in several cancers and other diseases. DNA Cell Biol 2017;36:77-94.

140. Kawaguchi T, Komatsu S, Ichikawa D, Morimura R, Tsujiura M, et al. Clinical impact of circulating miR-221 in plasma of patients with pancreatic cancer. Br J Cancer 2013;108:361-9.

141. Mirzaei HR, Sahebkar A, Mohammadi M, Yari R, Salehi H, et al. Circulating microRNAs in hepatocellular carcinoma: potential diagnostic and prognostic biomarkers. Curr Pharm Des 2016;22:5257-69.

142. Caivano A, La Rocca F, Simeon V, Girasole M, Dinarelli S, et al. MicroRNA-155 in serum-derived extracellular vesicles as a potential biomarker for hematologic malignancies - a short report. Cell Oncol (Dordr) 2017;40:97-103.

143. Ono S, Lam S, Nagahara M, Hoon DS. Circulating microRNA biomarkers as liquid biopsy for cancer patients: pros and cons of current assays. J Clin Med 2015;4:1890-907.

144. Mashouri L, Yousefi H, Aref AR, Ahadi AM, Molaei F, et al. Exosomes: composition, biogenesis, and mechanisms in cancer metastasis and drug resistance. Mol Cancer 2019;18:75.

145. Simpson RJ, Lim JWE, Moritz RL, Mathivanan S. Exosomes: proteomic insights and diagnostic potential. Expert Rev Proteom 2009;6:267-83.

146. Roma-Rodrigues C, Fernandes AR, Baptista PV. Exosome in tumour microenvironment: overview of the crosstalk between normal and cancer cells. Biomed Res Int 2014;2014:179486.

147. Spugnini EP, Logozzi M, Di Raimo R, Mizzoni D, Fais S. A role of tumor-released exosomes in paracrine dissemination and metastasis. Int J Mol Sci 2018;19:E3968.

148. Yousafzai NA, Wang H, Wang Z, Zhu Y, Zhu L, et al. Exosome mediated multidrug resistance in cancer. Am J Cancer Res 2018;8:2210-26.

149. Li I, Nabet BY. Exosomes in the tumor microenvironment as mediators of cancer therapy resistance. Mol Cancer 2019;18:32.

150. Guo Y, Ji X, Liu J, Fan D, Zhou Q, et al. Effects of exosomes on pre-metastatic niche formation in tumors. Mol Cancer 2019;18:39.

151. Qiao F, Pan P, Yan J, Sun J, Zong Y, et al. Role of tumor-derived extracellular vesicles in cancer progression and their clinical applications (Review). Int J Oncol 2019;54:1525-33.

152. Roma-Rodrigues C, Mendes R, Baptista PV, Fernandes AR. Targeting tumor microenvironment for cancer therapy. Int J Mol Sci 2019;20:E840.

153. Logozzi M, Spugnini E, Mizzoni D, Di Raimo R, Fais S. Extracellular acidity and increased exosome release as key phenotypes of malignant tumors. Cancer Metastasis Rev 2019;38:93-101.

154. Weston WW, Ganey T, Temple HT. The relationship between exosomes and cancer: implications for diagnostics and therapeutics. BioDrugs 2019;33:137-58.

155. Aghebati-Maleki A, Nami S, Baghbanzadeh A, Karzar BH, Noorolyai S, et al. Implications of exosomes as diagnostic and therapeutic strategies in cancer. J Cell Physiol 2019;234:21694-706. 
156. Bellassai N, D’Agata R, Jungbluth V, Spoto G. Surface plasmon resonance for biomarker detection: advances in non-invasive cancer diagnosis. Front Chem 2019;7:570.

157. Dorayappan KDP, Gardner ML, Hisey CL, Zingarelli RA1, Smith BQ, et al. A microfluidic chip enables isolation of exosomes and establishment of their protein profiles and associated signaling pathways in ovarian cancer. Cancer Res 2019;79:3503-13.

158. Li P, Yu X, Han W, Kong Y, Bao W, et al. Ultrasensitive and reversible nanoplatform of urinary exosomes for prostate cancer diagnosis. ACS Sens 2019;4:1433-41.

159 Taylor DD, Gercel-Taylor C. MicroRNA signatures of tumor-derived exosomes as diagnostic biomarkers of ovarian cancer. Gynecol Oncol 2008;10:13-21.

160. Meng X, Muller V, Milde-Langosch K, Trillsch F, Pantel K H. et al. Diagnostic and prognostic relevance of circulating exosomal miR373, miR-200a, miR-200b and miR-200c in patients with epithelial ovarian cancer. Oncotarget 2016;7:16923-35.

161. Giannopoulou L, Zavridou M, Kasimir-Bauer S, Lianidou ES. Liquid biopsy in ovarian cancer: the potential of circulating miRNAs and exosomes. Transl Res 2019;205:77-91.

162. Li Y, Zhang Y, Qiu F, Qiu Z. Proteomic identification of exosomal LRG1: a potential urinary biomarker for detecting NSCLC. Electrophoresis 2011;32:1976-83.

163. Weber DG, Johnen G, Casjens S, Bryk O, Pesch B, et al. Evaluation of long noncoding RNA MALAT1 as a candidate blood-based biomarker for the diagnosis of non-small cell lung cancer. BMC Res Notes 2013;6:518.

164. Liu S, Zhan Y, Luo J, Feng J, Lu J, et al. Roles of exosomes in the carcinogenesis and clinical therapy of non-small cell lung cancer. Biomed Pharmacother 2019;111:338-46.

165. Ogata-Kawata H, Izumiya M, Kurioka D, Honma Y, Yamada Y, et al. Circulating exosomal microRNAs as biomarkers of colon cancer. PLoS One 2014;9:e92921.

166. Mousavi S, Moallem R, Hassanian SM, Sadeghzade M, Mardani R, et al. Tumor-derived exosomes: potential biomarkers and therapeutic target in the treatment of colorectal cancer. J Cell Physiol 2019;234:12422-32.

167. Melo SA, Luecke LB, Kahlert C, Fernandez AF, Gammon ST, et al. Glypican-1 identifies cancer exosomes and detects early pancreatic cancer. Nature 2015;523:177-82.

168. Zhou B, Xu JW, Cheng YG, Gao JY, Hu SY, et al. Early detection of pancreatic cancer: where are we now and where are we going? Int J Cancer 2017;141:231-41.

169. Kaplan RN, Riba RD, Zacharoulis S, Bramley AH, Vincent L, et al. VEGFR1-positive haematopoietic bone marrow progenitors initiate the pre-metastatic niche. Nature 2005;438:820-7.

170. Kaplan RN, Psaila B, Lyden D. Bone marrow cells in the 'pre-metastatic niche': within bone and beyond. Cancer Metastasis Rev 2006;25:521-9.

171. Hoshino A, Costa-Silva B, Shen TL, Rodrigues G, Hashimoto A, et al. Tumour exosome integrins determine organotropic metastasis. Nature 2015;527:329-35

172. Costa-Silva B, Aiello NM, Ocean AJ, Singh S, Zhang H, et al. Pancreatic cancer exosomes initiate pre-metastatic niche formation in the liver. Nat Cell Biol 2015;17:816-26.

173. Peinado H, Zhang H, Matei IR, Costa-Silva B, Hoshino A, et al. Pre-metastatic niches: organ-specific homes for metastases. Nat Rev Cancer 2017; 17:302-17.

174. Li J, Tian T, Zhou X. The role of exosomal shuttle RNA (esRNA) in lymphoma. Crit Rev Oncol Hematol 2019;137:27-34.

175. Yang C, Yang H, Liu J, Zhu L, Yu S, et al. Focus on exosomes: novel pathogenic components of leukemia. Am J Cancer Res 2019;9:1815-29.

176. Umezu T, Ohyashiki K, Kuroda M, Ohyashiki JH. Leukemia cell to endothelial cell communication via exosomal miRNAs. Oncogene 2013;32:2747-55.

177. Tadokoro H, Umezu T, Ohyashiki K, Hirano T, Ohyashiki JH. Exosomes derived from hypoxic leukemia cells enhance tube formation in endothelial cells. J Biol Chem 2013;288:34343-51.

178. Mineo M, Garfield SH, Taverna S, Flugy A, De Leo G, et al. Exosomes released by K562 chronic myeloid leukemia cells promote angiogenesis in a Src-dependent fashion. Angiogenesis 2012;15:33-45.

179. Taverna S, Amodeo V, Saieva L, Russo A, Giallombardo M, et al. Exosomal shuttling of miR-126 in endothelial cells modulates adhesive and migratory abilities of chronic myelogenous leukemia cells. Mol Cancer 2014;13:169.

180. Taverna S, Flugy A, Saieva L, Kohn EC, Santoro A, et al. Role of exosomes released by chronic myelogenous leukemia cells in angiogenesis. Int J Cancer 2012;130:2033-43.

181. Korkolopoulou P, Viniou N, Kavantzas N, Patsouris E, Thymara I, et al. Clinicopathologic correlations of bone marrow angiogenesis in chronic myeloid leukemia: a morphometric study. Leukemia 2003;17:89-97.

182. Vinhas R, Mendes R, Fernandes AR, Baptista PV. Nanoparticles - emerging potential for managing leukemia and lymphoma. Front Bioeng Biotechnol 2017;5:79.

183. Rogers A, Joe Y, Manshouri T, Dey A, Jilani I, et al. Relative increase in leukemia-specific DNA in peripheral blood plasma from patients with acute myeloid leukemia and myelodysplasia. Blood 2004;103:2799-801.

184. Mouliere F, EI Messaoudi S, Pang D, Dritschilo A, Thierry AR. Multi- marker analysis of circulating cell- free DNA toward personalized medicine for colorectal cancer. Mol Oncol 2014;8:927-41.

185. Gao YJ, He YJ, Yang ZL, Shao HY, Zuo Y, et al. Increased integrity of circulating cell- free DNA in plasma of patients with acute leukemia. Clin Chem Lab Med 2010;48:1651-6.

186. Hocking J, Mithraprabhu S, Kalff A, Spencer A. Liquid biopsies for liquid tumors: emerging potential of circulating free nucleic acid evaluation for the management of hematologic malignancies. Cancer Biol Med 2016;13:215-25.

187. Koutova L, Sterbova M, Pazourkova E, Pospisilova S, Svobodova I, et al. The impact of standard chemotherapy on miRNA signature in plasma in AML patients. Leuk Res 2015;39:1389-95. 
188. Cornelissen JJ, Gratwohl A, Schlenk RF, Sierra J, Bornhäuser M, et al. The European LeukemiaNet AML working party consensus statement on allogeneic HSCT for patients with AML in remission: an integrated-risk adapted approach. Nat Rev Clin Oncol 2012;9:579-90.

189. Quan J, Gao Y, Yang Z, Chen H, Xian JR, et al. Quantitative detection of circulating nucleophosmin mutations DNA in the plasma of patients with acute myeloid leukemia. Int J Med Sci 2015;12:17-22.

190. Falini B, Mecucci C, Tiacci E, Alcalay M, Rosati R, et al. Cytoplasmic nucleophosmin in acute myelogenous leukemia with a normal karyotype. N Engl J Med 2005;352:254-66.

191. Nakamura S, Yokoyama K, Shimizu E, Yusa N, Kondoh K, et al. Prognostic impact of circulating tumor DNA status post-allogeneic hematopoietic stem cell transplantation in AML and MDS. Blood 2019;133:2682-95.

192. Iriyama C, Tomita A, Hoshino H, Adachi-Shirahata M, Furukawa-Hibi Y, et al. Using peripheral blood circulating DNAs to detect CpG global methylation status and genetic mutations in patients with myelodysplastic syndrome. Biochem Biophys Res Commun 2012;419:662-9.

193. Suzuki Y, Tomita A, Nakamura F, Iriyama C, Shirahata-Adachi M, et al. Peripheral blood cell- free DNA is an alternative tumor DNA source reflecting disease status in myelodysplastic syndromes. Cancer Sci 2016;107:1329-37.

194. Yeh P, Dickinson M, Ftouni S, Hunter T, Sinha D, et al. Molecular disease monitoring using circulating tumor DNA in myelodysplastic syndromes. Blood 2017;129:1685-90.

195. Corrado C, Saieva L, Raimondo S, Santoro A, De Leo G, et al. Chronic myelogenous leukemia exosomes modulate bone marrow microenvironment through activation of epidermal growth factor receptor. J Cell Mol Med 2016;20:1829-39.

196. Raimondo S, Saieva L, Corrado C, Fontana S, Flugy A, et al. Chronic myeloid leukemiaderived exosomes promote tumor growth through an autocrine mechanism. Cell Commun Signal 2015;13:8.

197. Heidary M, Auer M, Ulz P, Heitzer E, Petru E, et al. The dynamic range of circulating tumor DNA in metastatic breast cancer. Breast Cancer Res 2014;16:421.

198. Ulz P, Auer M, Heitzer E. Detection of circulating tumor DNA in the blood of cancer patients: an important tool in cancer chemoprevention. Methods Mol Biol 2016;1379:45-68.

199. Van Roy N, Van der Linden M, Menten B, Dheedene A, Vandeputte C, et al. Shallow whole genome sequencing on circulating cellfree DNA allows reliable non-invasive copy number profiling in neuroblastoma patients. Clin Cancer Res 2017.

200. Adalsteinsson VA, Ha G, Freeman SS, Choudhury AD, Stover DG, et al. Scalable whole-exome sequencing of cell-free DNA reveals high concordance with metastatic tumors. Nat Commun 2017;8:1324.

201. Stover DG, Parsons HA, Ha G, Freeman S, Barry B, et al. Genomewide copy number analysis of chemotherapy resistant metastatic triple-negative breast cancer from cell-free DNA. J Clin Oncol 2018;78.

202. Wang J, Bettegowda C. Applications of DNA-based liquid biopsy for central nervous system neoplasms. J Mol Diagn 2017;19:24-34.

203. Ilie M, Hofman V, Long E, Bordone O, Selva E, et al. Current challenges for detection of circulating tumor cells and cell-free circulating nucleic acids, and their characterization in non-small cell lung carcinoma patients. What is the best blood substrate for personalized medicine? Ann Trans Med 2014;2:107.

204. Newman AM, Bratman SV, To J, Wynne JF, Eclov NC, et al. An ultrasensitive method for quantitating circulating tumor DNA with broad patient coverage. Nat Med 2014;20:548-54.

205. Molina-Vila MA, Mayo-de-las-Casas C, Giménez-Capitán A, Jordana-Ariza N, Garzón M, et al. Liquid biopsy in non-small cell lung cancer. Front Med 2016;3:69.

206. Diehl F, Schmidt K, Choti MA, Romans K, Goodman S, et al. Circulating mutant DNA to assess tumor dynamics. Nat Med 2008;14:985-90.

207. Kidess E, Jeffrey SS. Circulating tumor cells versus tumor-derived cell-free DNA: rivals or partners in cancer care in the era of singlecell analysis? Genome Med 2013;5:70.

208. Diaz LA, Bardelli A. Liquid biopsies: genotyping circulating tumor DNA. J Clin Oncol 2014;32:579-86. 